\title{
sciendo
}

DOI 10.2478/sbe-2019-0015

SBE no. 14(1) 2019

\section{TIME-DRIVEN ACTIVITY-BASED COSTING SYSTEMS FOR MARKETING DECISIONS}

\author{
PARK Yonpae \\ Savannah State University, USA \\ JUNG Sungwoo \\ Columbus State University, USA \\ JAHMANI Yousef \\ Savannah State University, USA
}

\begin{abstract}
:
The activity-based costing $(A B C)$ systems emerged as a management accounting innovation in the mid-1980s in response to dissatisfaction with traditional management accounting techniques and heightened international competition. Although ABC provides many advantages for managerial decision making, $A B C$ tends to be outdated due to its limitations and is substituted by the time-driven activity-based costing (TDABC) systems. TDABC requires estimates of only two parameters: how much it costs per time unit of capacity to supply resources to activities and how much time it takes to perform each activity. TDABC allows incorporation of variation in the time demands made by different types of processes and consequently the representation of all possible combinations of activities that a process performs. This paper uses TDABC to calculate marketing costs and describes TDABC as a useful technique to reduce marketing resource costs and to support effective marketing decision making in various contexts such as marketing processes restructuring, marketing mix choices, customer profitability and price differentiation for customer classes.
\end{abstract}

Key words: time-driven activity-based costing (TDABC); marketing cost; accounting

\section{Introduction}

Marketing costs have been increasing rapidly while manufacturing costs have been decreasing after the financial and economic crisis of 2008. For example, although U.S. advertising expenditures were reduced in anticipation of an economic downturn by $4.44 \%$ in 2008 and $16.26 \%$ in 2009, they have been increasing from $\$ 134.3$ billion in 2009 to $\$ 178.2$ billion in 2016 (see Table 1). On the other hand, the manufacturing cost competitiveness of U.S. improved substantially over the past decade because of low wage growth, sustained productivity gains, steady exchange rates, and a major energy-cost 
advantage (Minter 2014). Reflecting the increasing marketing costs, a well-developed costing system facilitating marketing cost tracking is becoming more important to companies. The marketing cost information can help managers in making decisions such as marketing process restructuring, marketing mix choices, customer profitability, price differentiation for customer classes, and so on. Those decision-makings rely heavily on the availability of relevant, reliable, and timely marketing cost information. To this end, managers heavily depend on the company's costing system to obtain such useful information needed to make decisions.

Table 1: U.S. Advertising Expenditures

\begin{tabular}{lll}
\hline Year & $\begin{array}{l}\text { Adverting Expenditures } \\
\text { millions) }\end{array}$ & in \\
\hline $\mathbf{2 0 1 6}$ & $\$ 178,204.2$ & $5.80 \%$ \\
\hline $\mathbf{2 0 1 5}$ & $\$ 168,435.0$ & $2.65 \%$ \\
\hline $\mathbf{2 0 1 4}$ & $\$ 164,080.4$ & $3.32 \%$ \\
\hline $\mathbf{2 0 1 3}$ & $\$ 158,813.9$ & $2.32 \%$ \\
\hline $\mathbf{2 0 1 2}$ & $\$ 155,215.6$ & $5.08 \%$ \\
\hline $\mathbf{2 0 1 1}$ & $\$ 147,710.4$ & $3.12 \%$ \\
\hline $\mathbf{2 0 1 0}$ & $\$ 143,241.7$ & $6.62 \%$ \\
\hline $\mathbf{2 0 0 9}$ & $\$ 134,349.4$ & $-16.26 \%$ \\
\hline $\mathbf{2 0 0 8}$ & $\$ 160,440.3$ & $-4.44 \%$ \\
\hline \multicolumn{2}{l}{ Source: WARC (http://www.warc.com) }
\end{tabular}

Current developments in cost accounting literature indicate the limitations of traditional costing systems and the emergence of new concepts, which include Value Chain Analysis, Activity-based Costing (ABC), Target Costing, Life Cycle Costing (LCC), and Kaizen Costing. Such concepts have forced accountants to break through the typical product costing barriers of traditional costing systems by applying cross-functional costs in a more relevant and enlightening way which is especially crucial for marketing decision makings. To provide maximum benefit, these new cost management concepts must be practically integrated into accounting systems, business processes, and strategies. Furthermore, marketing managers need effective tools to coordinate pursuing the customer value creation strategy and controlling the costs which their companies have to bear to create such value.

Traditional product costing methodologies, which apply only costs incurred in the manufacturing process to products and use one single cost driver, systematically distort product costs in modern manufacturing and service environments in which the percentage of overhead costs to total manufacturing costs has increased due to the diversification of products, complexity of processes, and manufacturing automation. A failure to allocate overhead costs accurately causes the costs of products to misrepresent the real consumption of the resources. Consequently, managers are unable to make correct decisions based on the misrepresented cost data of traditional costing (Narong 2009). On the other hand, $A B C$ has been introduced to overcome the problem of inaccurate allocation of costs in traditional costing. In $A B C$, activities consume resources and it becomes necessary to measure the consumption of these resources by activities which helps management to reduce costs by minimizing the cost of non-value added activities. ABC also views products as the result of the various activities and allocates their costs to the 
products through a variety of cost drivers based on the cause-and-effect relationships between costs in activity cost pools and cost drivers.

Despite the advantages over traditional costing, problems related to $A B C$ have emerged and many companies terminated its application or stopped its development. These problems are related to the costs associated with surveying the employees to find out how their works are allocated on a daily basis and the time spent in this process, the costs related to data storage, processing and reporting when the current accounting system does not support $A B C$ data, the difficulty in updating the system to accommodate changing circumstances, and the ignorance of unused capacity (Kaplan and Anderson 2007). Due to those shortcomings of ABC, Kaplan and Anderson (2003) developed a new costing system called Time-Driven Activity-Based Costing (TDABC) method which avoids the costly and time-consuming surveying process and presents more accurate information about a company's complex activities by deriving suitable time equation models. This paper uses TDABC instead of conventional $A B C$ because in the complex and dynamic environment of marketing area, cost system needs to quickly adapt to changing circumstances, to provide accurate cost information at a low cost manner, and to support effective marketing decisions in various contexts.

\section{Marketing Cost Analysis}

Marketing is important for the growth of a company and many companies spend billions of dollars on marketing. For instance, Procter and Gamble, the largest advertiser in the U.S. spent over $\$ 4.3$ billion in 2015 . Weber (2002) found that over the past 50 years, marketing costs have risen rapidly from $20 \%$ to $50 \%$ of total corporate costs while the manufacturing costs have declined from $50 \%$ to $30 \%$ of total corporate costs and the general management costs have also declined from $30 \%$ to $20 \%$. Marketing costs are expected to increase proportionately more than manufacturing and general management costs as the intensity of competition from local, regional, national, and multinational companies is growing. Given these large marketing investments, management has to optimally allocate resources and explain that these investments bring appropriate profits to the company. However, many managers rely on simple heuristics and decision rules for resource allocation such as percentage-of-sales rule for the allocation of marketing resources (Lilien, Kotler, and Moorthy 1992).

It has been observed that companies frequently look to market share, sales volume, or sales revenue when trying to attain profit goals. The traditional accounting system fails reporting customer profitability information to support analysis for which types of marketing functions improve profitability. While most refined tools of cost control have been applied in the manufacturing process, nothing like time studies, motion analysis, statistical cost control, and standard cost accounting have been developed in the area of marketing cost analysis. Foster and Gupta (1994) emphasized a need for understanding the nature of marketing costs and for developing measures that can evaluate both efficiency and effectiveness of marketing functions. Today's marketing technology enables us to identify which types of customers to work with to make a sale, right down to individual 
customer level through very intelligent, extremely cost effective digital techniques, advanced marketing automation, modern website technologies, social media, and so on.

\section{Activity-Based Costing (ABC)}

The traditional costing method prevailed when direct materials and labor were the predominant resources for companies, indirect costs were low, technology were stable, and there was a limited range of products or services. In this environment, managers were encouraged to manage the allocation and absorption of indirect costs rather than strive to reduce waste and enhance efficiency (Brimson 1991). The activity-based costing (ABC) is an advanced costing approach that seeks to remedy such a limitation of traditional costing method (Kaplan and Cooper 1998). ABC, the best-known management accounting innovation in the mid-1980s, takes into account the cost incurred at the activity level and then attributes the cost to products according to the activities that a product goes through (Spedding and Sun 1999). ABC is a logical approach to the management of the company, which helps to clarify and to assess a company's processes and identify their cost. The idea behind $A B C$ is that products or services consume activities and then activities consume resources.

This study presents the application of $A B C$ to the cost allocation in the marketing functions. Beik and Buzby (1973) stated that cost analysis from the viewpoint of marketing decision provides useful information needed to plan and control marketing costs and to devise appropriate marketing strategies for selling products. Marketing costs are those which arise out of the activities of market delineation, purchase motivation, adjustment of the product to meet customer demands, communication of the seller's message to the customer, and physical distribution. These are costs incurred after products or services have been made available for sale. The marketing cost analysis centers on the allocation of relevant costs to the cost objects; objects of particular interest in the cost analysis, such as product, customer, territory, channel, and others for which costs are incurred. When the general ledger is selected as the source of cost data, ABC system usually classifies costs in a department/cost center's general ledger with similar cost behavior patterns separated into the multiple activity cost pools (Brimson 1991). In general, employees and equipment are interviewed or reviewed to understand their activities and to determine the time spent on different activities in ABC system. Then, the total department or cost center costs are assigned to each activity pool according to the percentage of time that employees or equipment spend on performing activities.

The number of distinct marketing functions may vary and such may be due to types of products sold, the diversity and expanse of markets, and perhaps the size of the company. This study uses the typical marketing functions which Beik and Buzby (1973) grouped as follows:

- Advertising - This includes all forms of non-personal promotion. The degree of knowledge possessed by the customer about products, services, or company is one of factors which bring about cost differences. The less knowledgeable the 
market is, the more advertising is necessary for the product or service. The extent or amount of advertising activities is also a cost determining factor.

- Selling - This includes all promotional or selling activities through the employment of the sales force. Selling efforts are affected by the density of the market, i.e., the number of customers within a given market area. The length in time and number of sales calls are functions of market density. Thus, time and number of sales calls can be appropriate cost drivers for selling.

- Warehousing - This includes activities undertaken to keep goods available and ready for delivery to customers. Warehousing costs such as insurance, storage, interest, and inventory control vary with the average investment in inventory and with the space and time for warehousing requirements.

- Shipping - This covers activity necessary to ensure that the right product is available to the customer at the right time and right place. Shipping costs are affected by distance from the market as well as by volume (i.e., handling units and weight of shipment).

The broad marketing functions can be subdivided into activities. The appropriate degree of disaggregation depends on the economics of the activities and the purposes for which the cost is being analyzed. In this respect, the basic principle is that activities should be separated if they (1) have different economics (i.e., cost behavior), (2) have a high potential impact on differentiation, or (3) represent a significant proportion of cost. Then, the company has to search for underlying causes of cost differences in the activity of each function. This factor of variability in costs serves as the cost drivers. A cost driver is the unit of an activity that drives the change of cost.

The mechanism of $A B C$ requires going through several steps. The cost allocation involves a systematic process in which costs are first assigned to activity pools and then the activity costs are allocated to products or other cost objects based on each product or other cost object demand for, or consumption of the activities. While traditional costing method relies on arbitrary allocation of indirect costs, $A B C$ classifies activity pools according to the activities performed within the company. The following Table 2 summarizes conventional $A B C$ steps:

Table 2: Conventional Activity-Based Costing Steps

\begin{tabular}{|c|c|}
\hline Step 1 & Identification of activity pools \\
\hline Step 2 & Assigning resource costs to each activity pool \\
\hline Step 3 & Determining cost drivers for each activity pool \\
\hline Step 4 & Calculating activity rate of each activity pool* \\
\hline Step 5 & $\begin{array}{l}\text { Multiplying the activity rate of each activity pool by the actual quantity of cost driver used } \\
\text { by a particular cost object }\end{array}$ \\
\hline
\end{tabular}

Although $A B C$ provides interesting advantages for managerial decision making in companies, $A B C$ also has its limitations. $A B C$ is difficult and costly to implement and maintain, especially when the current accounting system does not support the collection of ABC information (Kaplan and Anderson 2004, 2007). Data collection is time consuming and costly because of the need to interview and survey the employees to estimate the 
percentage of time spent on activities they performed and to assign the resource cost to the activity cost pools according to the percentage from the survey. Furthermore, employee resistance could arise, as they might feel threatened by the suggestion that their work should be improved. As a consequence, the conventional activity-based costing system tends to be outdated and substituted by less demanding and more accurate approaches such as Time-Driven Activity-Based Costing (Wegmann and Nozile 2009).

\section{Time-Driven Activity-Based Costing (TDABC)}

The time-driven activity-based costing (TDABC) method was developed by Robert Kaplan and Steve Anderson in 2004 to overcome the difficulties presented by previous costing systems. TDABC is a simpler, less costly, and more accurate than conventional $A B C$ as only two parameters are required: 1) the cost per hour (or minute) to supply practical capacity of the resources and 2) the number of hours (or minutes) required to perform the activities related to the cost objects. In other words, it is necessary to determine the capacity cost rate and the time duration to perform the activities carried out by each cost object. Both parameters are easily identifiable. Unlike the percentage that employees subjectively estimate to assign resource costs to each activity pool in conventional $A B C$, the time duration required to perform a certain activity can be readily observed and validated in TDABC. Practical capacity is often estimated as a percentage, for instance, $80 \%$ of theoretical capacity. That is, if an employee can normally work 40 hours per week, practical capacity could be assumed to be 32 hours per week. This estimate allows for $20 \%$ of personnel time for breaks, arrival and departure, and communication and reading unrelated to actual work performance. It is also very important to stress, though, that the question is not about the percentage of time an employee spends doing an activity, but how long it takes to complete one unit of that activity (for example, how much time it takes to deal with one order request). Knowing the practical capacity of the resources used and the time spent on activities, it is possible to determine the cost of each activity by multiplying the time spent on activities by the unit cost of supplying practical capacity of the resources (Kaplan \& Anderson, 2004; Kaplan \& Anderson, 2007). The steps for the cost calculation of the TDABC is as follows:

Table 3: Time-Driven Activity-Based Costing Steps

Step 1 Estimation of the total cost of resource supplied

Step 2 Estimation of the practical capacity of resource supplied

Step 3 Calculation of the capacity cost rate*

Step 4 Estimation of the unit times to perform sub-activities for each primary activity

Step 5 Multiplying the capacity cost rate by the total time of each primary activity performed for a particular cost object

${ }^{*}$ Capacity cost rate $=$ Cost of resource supplied $\div$ Practical capacity of resources supplied

Contrary to conventional $A B C$, with time-driven $A B C$ resource costs are not first assigned to specific activities; they are pooled at a higher level (department or process) in the company and resource usage is directly estimated by employing time equations, which express the time required to perform a certain activity as a function of several time drivers (Hoozee et al. 2012). The cost of the activity is then calculated by multiplying the estimated time from time equation by the cost per time unit of the resources needed to perform the activity (i.e., capacity cost rate). 


\section{Application of Conventional ABC}

This study assumes that $X Y Z$ company selling quality tools is currently generating an overall loss which is attributed mainly to the high marketing costs for individual customers. The company's management has applied a strategy based on the expectation that some high-demanding customers may be unprofitable and today's unprofitable customer can be tomorrow's profitable one. With such expectation, the company is to determine if their retailers or wholesalers are profitable enough to enable the company to recover the marketing costs expended on acquisition of individual customers. Hence, marketing managers need relevant information about which types of customers to acquire, retain, grow, or win-back. In the following analysis, cost objects are classified according to different types of customer group such as individual customers, retailers, and wholesalers. Costs which can be traced to a particular cost object are considered "direct." Costs which cannot be associated with a particular cost object are defined as "indirect" which is the focus of the $A B C$ analysis. A review of the marketing department's general ledger reveals the cost listed in Panel I of Table 4. Assume that the total marketing cost for a month is indirect and $\$ 150,000$ as indicated. In conventional $A B C$, indirect costs are assigned to cost objects using an activity driver. This study assumes that 10 employees in the marketing department are working 8 hours per day and 20 working days a month. Therefore, the marketing department has 1,600 hours (96,000 minutes) of available capacity in employee time. The company's major marketing activities (which cause indirect marketing costs) are identified. Overall, 5 major marketing activities are identified for use in the following analysis.

\section{Table 4: Cost Allocation in Conventional ABC}

Panel I: General Ledger Costs of the Marketing Department

\begin{tabular}{ll}
\hline Account & Amount \\
\hline Payroll & $\$ 40,000$ \\
\hline Office Supplies & $\$ 10,000$ \\
\hline Maintenance & $\$ 30,000$ \\
\hline Depreciation for Computer Equipment & $\$ 25,000$ \\
\hline Rent & $\$ 20,000$ \\
\hline Meals \& Entertainment & $\$ 5,000$ \\
\hline Legal \& Professional & $\$ 10,000$ \\
\hline Utilities & $\$ 10,000$ \\
\hline Total & $\$ 150,000$ \\
\hline
\end{tabular}

Panel II: Marketing Activities Information

\begin{tabular}{|c|c|c|c|c|c|}
\hline Activity & $\begin{array}{l}\% \text { of Time } \\
\text { Spent }\end{array}$ & $\begin{array}{l}\text { Assigned } \\
\text { Cost }\end{array}$ & Cost Driver & $\begin{array}{l}\text { Activity } \\
\text { Level }\end{array}$ & $\begin{array}{l}\text { Activity } \\
\text { Rate }\end{array}$ \\
\hline Advertising & $40 \%$ & $\$ 60,000$ & $\begin{array}{l}\text { Number } \\
\text { messages }\end{array}$ & $\begin{array}{l}5,000 \\
\text { messages }\end{array}$ & $\$ 12.00 /$ message \\
\hline Selling & $10 \%$ & 15,000 & $\begin{array}{l}\text { Number of sales } \\
\text { orders }\end{array}$ & 1,000 orders & $\$ 15.00 /$ order \\
\hline Warehousing & $20 \%$ & 30,000 & Number of & 4,100 picks & \$7.32/picking \\
\hline
\end{tabular}


Studies in Business and Economics no. 14(1)/2019

\begin{tabular}{|c|c|c|c|c|c|c|}
\hline \multicolumn{7}{|c|}{ pickings } \\
\hline Shipping & $30 \%$ & 45,000 & $\begin{array}{l}\text { Number } \\
\text { loadings }\end{array}$ & of & 2,600 loads & $\$ 17.31 /$ loading \\
\hline Total & $100 \%$ & $\$ 150,00$ & & & & \\
\hline
\end{tabular}

Panel III: Cost Driver Information for the Cost Objects

\begin{tabular}{llll}
\hline Cost Driver & \multicolumn{1}{c}{ Individual } & \multicolumn{1}{c}{ Retailer } & Wholesaler \\
\hline Number of messages & 3,000 & 1,500 & 500 \\
\hline Number of sales orders & 500 & 300 & 200 \\
\hline Number of pickings & 2,000 & 1,500 & 600 \\
\hline Number of loadings & 500 & 1,500 & 600 \\
\hline
\end{tabular}

Panel IV: Cost Allocation

\begin{tabular}{|c|c|c|c|}
\hline \multirow[b]{2}{*}{ Activity } & \multicolumn{3}{|c|}{ Cost Object } \\
\hline & Individual & Retailer & Wholesaler \\
\hline Advertising $(\$ 12.00 \times 3,000 ; 1,500 ; 500)$ & $\$ 36,000.00$ & $\$ 18,000.00$ & $\$ 6,000.00$ \\
\hline Selling $\quad(\$ 15.00 \times 500 ; 300 ; 200)$ & $\$ 7,500.00$ & $\$ 4,500.00$ & $\$ 3,000.00$ \\
\hline Warehousing $(\$ 7.32 \times 2,000 ; 1,500 ; 600)$ & $\$ 14,634.15$ & $\$ 10,975.61$ & $\$ 4,390.24$ \\
\hline Shipping $\quad(\$ 17.31 \times 500 ; 1,500 ; 600)$ & $\$ 8,653.85$ & $\$ 25,961.54$ & $\$ 10,384.62$ \\
\hline Total & $\$ 66,787.99$ & $\$ 59,437.15$ & $\$ 23,774.86$ \\
\hline
\end{tabular}

For the marketing department, employees are surveyed to estimate the percentage of their time spent (or that they expect to spend) on the four major marketing activities they perform. Suppose they estimate these percentages as $40 \%, 10 \%, 20 \%$, and $30 \%$ respectively. The data in Panel II of Table 4 present these activities and their cost drivers and Panel III summarizes information about the actual quantity of cost drivers used by each of 3 customer types. The indirect marketing costs can be driven by various customers, some of whom place more demands on the company resources than others. For instance, some customers may require standard delivery or less advertising spends whereas others demand special delivery requirements or intensive advertising. Each of activities has an indirect marketing cost that can be allocated to the specific customer using activity rate. For example, advertising costs $\$ 60,000$ and total number of messages (i.e., emails or catalogs) is 5,000 . Thus, activity rate for advertising is $\$ 12$ per message. This calculation is repeated for each activity and the amount of indirect marketing cost is allocated to each cost object. The cost allocation for each cost object is summarized in Panel IV of Table 4.

\section{Application of TDABC}

The first step in developing TDABC system is to determine the total costs of resources supplied to perform activities in a given entity (i.e., department or process); the general ledger costs incurred at the marketing department in this study. As indicated in Panel I of Table 4, the marketing department's general ledger shows the total cost as $\$ 150,000$. The second step in developing TDABC system is to estimate a marketing department's practical capacity which is measured in units of time. The company has 10 frontline employees in the marketing department and each of these employees is working 8 hours per day, with two 15-minute paid breaks per day, on average 20 working days a month. Therefore, the marketing department has 90,000 minutes (i.e., 10 employees $\times 7.5$ 
hours per day $\times 20$ days per month $\times 60$ minutes per hour) of practical capacity in employee time. The third step is to estimate its capacity cost rate. The capacity cost rate $\left(C_{d}\right)$ for an entity $(d)$ is calculated by dividing total cost of resources supplied by practical capacity as follows:

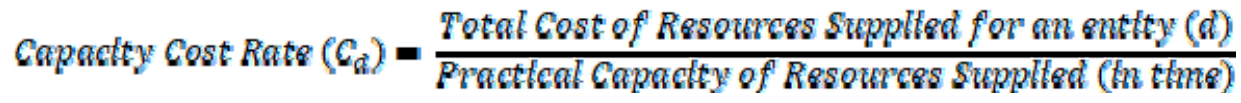

The capacity cost rate of the marketing department is $\$ 1.67$ per minute (i.e., $\$ 150,000 \div 90,000$ minutes). The fourth step is developing time equations for each of the four primary activities in the marketing department. TDABC system uses time estimates (in minutes) as a common measure across all the activities and the time equations represent how distinct characteristics of sub-activities consume process time in the marketing department. For examples, the time to enter a sales order information into the company's computer system is different for a new customer compared to an existing customer. When the capacity cost rate is multiplied by the time to process each customer's sales order, TDABC measures the cost of the different amount of resources consumed to serve new or existing customer's sales orders. The fifth and final step is determining the indirect costs allocated to each cost object by multiplying the capacity cost rate by the total time used to perform each activity. Figure 1 represents the steps of cost allocation in TDABC system.

Kaplan and Anderson (2007) indicate that TDABC accommodates the complexity of real-world operations by incorporating much simplified time equations that enables the model to reflect how activities cause processing times to vary. The process time consumed by different activities can be estimated by means of direct observations or interviews with employees. The conventional $A B C$ surveys ask employees to estimate the percentage of their total time that each activity consumes over a three- or six-month period. But in the TDABC surveys, employees find it far easier to estimate the time required to perform a specific activity and the direct observation provides more accurate measurement that can be done in minutes or hours, rather than three- or six-month periods. Therefore, TDABC system can be updated easily to reflect changes in activities by simply measuring the time required for any new activity. On the other hand, Conventional $A B C$ is not accurate or granular enough to capture the complexity of actual operations. For examples, company can ship items to domestic customers or overseas customers, by standard or overnight express, and by ground or air. Each variation of the shipping process leads to different demands of resources. In conventional $A B C$, new activities have to be added to the model in order to handle such variation and employees must be re-interviewed and asked to reestimate the percentage of their total time across more complex set of activities, which generally results in more subjective and inaccurate cost assignment to different activity pools. 
Studies in Business and Economics no. 14(1)/2019

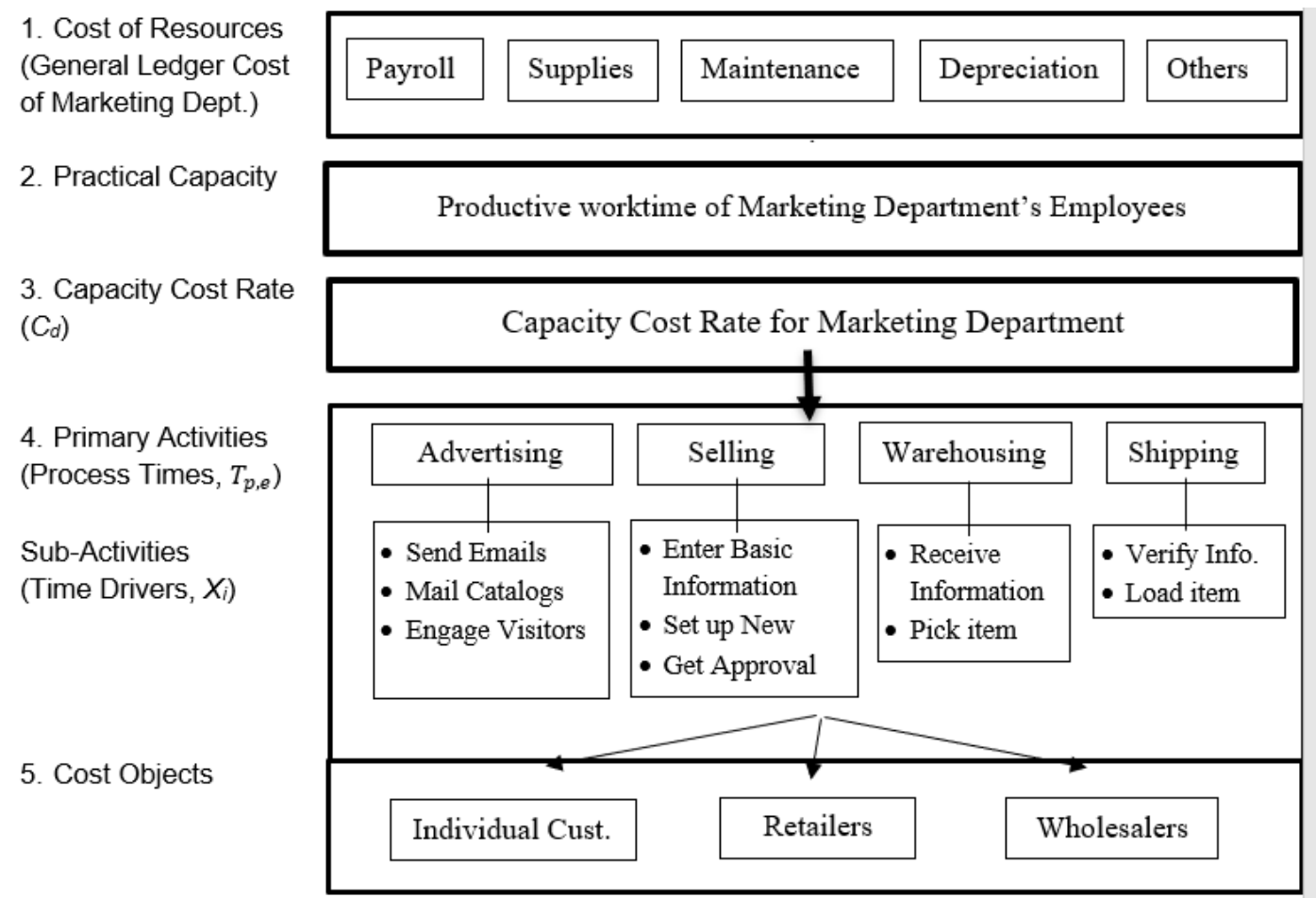

Figure 1. Cost Allocation in TDABC

In conventional $A B C$, the complexity of activity causes the quantity of data estimates, storage, and processing to increase exponentially with the number of activity variations (Kaplan and Anderson 2007). However, TDABC formulates the time equation to represent the process time $(t)$ required to perform a specific activity $(p)$ associated with several sub-activities (i.e., activity variations) ( $i$ ) as follows (Everaert and Bruggeman 2007).

$T_{p, \varepsilon}=\beta_{0}+\beta_{1} X_{1}+\beta_{2} X_{2}+\beta_{8} X_{8}+\cdots+\cdots+\beta_{i} X_{i}$

where

$T_{p, e}=$ total process time required to perform an activity $(p)$ for cost object $(e)$

$X_{i}=$ quantity of time driver for sub-activity $i$,

$\beta_{0}=$ basic time for performing the activity $p$, and

$\beta_{i}=$ estimated time duration for one unit of time driver for sub-activity $i$.

The time driver $\left(X_{i}\right)$ in the above time equation is a measure which affects the time duration to perform a certain sub-activity. Everaert and Bruggeman (2007) point that it can be a continuous variable (i.e., weight of an item), a discrete variable (i.e., number of items), or indicator variable (i.e., 1 if a new customer; 0 otherwise). The time equation in TDABC system expands only linearly with additional sub-activities, not exponentially as in conventional $\mathrm{ABC}$. By multiplying the process time $\left(T_{p, e}\right)$ by the capacity cost rate $\left(C_{d}\right)$, the cost of a specific activity $(p)$ is determined and the cost allocated to a specific cost object 
(e) can be calculated by adding the costs incurred to perform all activities for the cost object as follows:

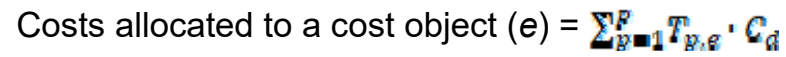

where

$T_{p, e}=$ total process time required to perform an activity $(p)$ for cost object $(e)$,

$C_{d}=$ capacity cost rate for an entity $d$,

$P=$ number of primary activities

This study illustrates the development of time equations and the cost allocation in TDABC system for the following primary activities in a marketing department.

\section{Advertising Process}

The process of advertising products cannot be driven simply by the amount of sales, as in a conventional $A B C$. The process requires multiple drivers to represent all the factors influencing actual processing time. The marketing department applies a standardized process to plan, design, and prepare any types of advertising campaigns (i.e., email, catalog, and trade show), which takes an average of 5 hours (i.e., 300 minutes) per month. In addition, the marketing employees send promotion emails and product catalogs to customers registered in a company's computer system on a one-to-one basis. They also participate in trade shows and gather contact information from visitors at the booth. A promotional email takes an average of 1 minute to send each email. It takes an average of 3 minutes to mail each catalog. In case of trade show, it takes an average of 10 minutes to engage each visitor. The data about sub-activities associated with advertising process are listed in Table 5.

Table 5: Advertising Process

\begin{tabular}{lll}
\hline \multicolumn{1}{c}{ Sub-activity } & Time Driver & Time Consumption \\
\hline $\begin{array}{l}\text { Plan, design, and prepare Ad campaigns } \\
\text { (basic activity) }\end{array}$ & - & 300 minutes \\
\hline Send emails to customers & Number of emails & 1 minutes/email \\
\hline Mail catalogs to customers & Number of catalogs & 3 minutes/catalog \\
\hline $\begin{array}{l}\text { Engage and gather visitor's contact } \\
\text { information in trade shows }\end{array}$ & Number of visitors & 10 minutes/visitor \\
\hline
\end{tabular}

The time equation for advertising process during a month is as follows:

Advertising Process Time $=300$ minutes

+1 minute $\times$ number of emails sent

+3 minutes $\times$ number of catalogs mailed

+10 minutes $\times$ number of trade show visitors

$=300+1 X_{1}+3 X_{2}+10 X_{3}$

where $X_{1}=$ number of emails sent

$\mathrm{X}_{2}=$ number of catalogs mailed

$\mathrm{X}_{3}=$ number of trade show visitors 
We assume that during a month, the marketing department sends 2,000 emails and 1,000 catalogs to individual customers and gather contact information of 300 individual customers and the data for retailers and wholesalers are collected similarly as shown in Table 6.

Table 6: Cost Allocation for Advertising Process

\begin{tabular}{|c|c|c|c|c|c|c|}
\hline $\begin{array}{l}\text { Cost } \\
\text { Object }\end{array}$ & Email & Catalog & $\begin{array}{l}\text { Trade } \\
\text { Show }\end{array}$ & $\begin{array}{l}\text { Process } \\
\text { Time* }\end{array}$ & $\begin{array}{l}\text { Capacity Cost } \\
\text { Rate }\end{array}$ & $\begin{array}{l}\text { Cost } \\
\text { Allocated** }\end{array}$ \\
\hline Individual & 2,000 & 1,000 & 300 & 8,300 minutes & $\$ 1.67 / \mathrm{min}$ & $\$ 13,833.33$ \\
\hline Retailer & 1,000 & 500 & 50 & 3,300 minutes & $\$ 1.67 / \mathrm{min}$ & $\$ 5,500.00$ \\
\hline Wholesaler & 300 & 200 & 5 & 1,250 minutes & $\$ 1.67 / \mathrm{min}$ & $\$ 2,083.33$ \\
\hline Total & & & & 12,850 minutes & & $\$ 21,416.67$ \\
\hline
\end{tabular}

\section{Selling Process}

The direct observation about selling process in the marketing department shows that it takes an average of 5 minutes to enter a basic order information into the computer system plus 2 minutes for each line item. If the order is from a new customer, additional 10 minutes will be required to set up a new account in the computer system. The orders from retailers or wholesalers have to be approved and it takes additional 8 minutes to be approved. The data about selling process are summarized in Table 7.

Table 7: Selling Process

\begin{tabular}{lll}
\hline Activity & Time Driver & Time Consumption \\
\hline $\begin{array}{l}\text { Enter a basic order information (basic } \\
\text { activity) }\end{array}$ & 5 minutes \\
\hline Set up a new account for a new customer & 10 minutes/new \\
\hline Get an approval for retailer or wholesaler & $\begin{array}{l}\text { minutes/retailer } \\
\text { wholesaler }\end{array}$ \\
\hline Enter the order information of items & Number of line items & 2 minutes/item \\
\hline
\end{tabular}

TDABC system groups the multiple sub-activities of selling process into the following time equation to estimate process time per sales order:

Selling Process Time $=5$ minutes

(+ 10 minutes if ordered by new customer)

( +8 minutes if ordered by retailer or wholesaler)

+2 minutes $\times$ number of line items in each order

$=5+10 X_{1}+8 X_{2}+2 X_{3}$

where $X_{1}=$ new customer (1) / existing customer (0)

$\mathrm{X}_{2}=$ retailer or wholesaler $(1) /$ individual customer $(0)$

$\mathrm{X}_{3}=$ number of line items

We assume that during a month, the marketing department processes 500 orders from individual customers and each order has an average of 4 items. 300 orders from retailers are processed and each order has 5 cases on average. 200 orders from wholesalers are processed and each order has an average of 3 pallets. On average, $10 \%$ 
of orders are from new customers. The cost allocation for selling process in a TDABC system is provided in Table 8 .

Table 8: Cost Allocation for Selling Process

\begin{tabular}{|c|c|c|c|c|c|c|}
\hline $\begin{array}{l}\text { Cost } \\
\text { Object }\end{array}$ & $\begin{array}{l}\text { Existing } \\
\text { Customer }\end{array}$ & $\begin{array}{l}\text { New } \\
\text { Customer }\end{array}$ & $\begin{array}{l}\text { Line } \\
\text { Item }\end{array}$ & $\begin{array}{l}\text { Process } \\
\text { Time* }\end{array}$ & $\begin{array}{l}\text { Capacity Cost } \\
\text { Rate }\end{array}$ & $\begin{array}{l}\text { Cost } \\
\text { Allocated** }\end{array}$ \\
\hline Individual & 450 & 50 & 4 & 7,000 minutes & $\$ 1.67 / \mathrm{min}$ & $\$ 11,666.67$ \\
\hline Retailer & 270 & 30 & 5 & 7,200 minutes & $\$ 1.67 / \mathrm{min}$ & $\$ 12,000.00$ \\
\hline Wholesaler & 180 & 20 & 3 & 4,000 minutes & $\$ 1.67 / \mathrm{min}$ & $\$ 6,666.67$ \\
\hline Total & & & & 18,200 minutes & & $\$ 30,333.33$ \\
\hline \multicolumn{7}{|c|}{$\begin{array}{l}\text { * Process Time for Individual Customer }=(5+2 \times \text { Items }) \times \text { Existing Individual Customers }+ \\
(5+10+2 \times \text { Items }) \times \text { New Individual Customers }\end{array}$} \\
\hline \multicolumn{7}{|c|}{$\begin{array}{l}\text { Process Time for Retailer }=(5+8+2 \times \text { Cases }) \times \text { Existing Retailers }+(5+10+8+2 \times \\
\text { Cases }) \times \text { New Retailers }\end{array}$} \\
\hline \multicolumn{7}{|c|}{$\begin{array}{l}\text { Process Time for Wholesaler }=(5+8+2 \times \text { Pallets }) \times \text { Existing Wholesaler }+(5+10+8+ \\
2 \times \text { Pallets }) \times \text { New Wholesalers }\end{array}$} \\
\hline
\end{tabular}

\section{Warehousing Process}

The warehouse operation can be either storing products or handling products. The resources for storing process include the building, fixtures, and personnel performing building maintenance, housekeeping, and security functions (Kaplan and Anderson 2007). The resources for handling process include personnel performing picking and packing and the equipment to transport products such as conveyors and forklifts. The handling process time can be affected by factors such as types of the product being handled, total number of orders, picks per order, quantity per pick, packaging, and how to handle piece pick, case pick, or full-pallet loads. This study assumes that the storing process is managed by facility department and the handling process by marketing department.

The marketing department uses a combination of picking methods to serve the special requirements of the three types of customers. To serve a specific order from an individual customer, the warehouse operator picks items from static shelves one-by-one and carries them to the packing station. As assumed earlier, each order has an average of 4 items (i.e., number of cartons $=1 / 4$ of items). Then, the packer at a packing station fills empty spaces in a carton (including 4 items on average) with filler material to minimize damage during shipment and push the packed cartons onto the spur conveyor to transport them to the shipping dock. To serve retailers, conveyor systems are used to move the cases from a case picking zone to the shipping dock at the end of convey process. To serve wholesalers, the warehouse operators retrieve the pallet load from pallet racks by forklifts, wrap the pallet load with the stretch film, and move it directly to the shipping dock. The data about warehousing process are summarized in Table 9.

Table 9: Warehousing Process

\begin{tabular}{lll}
\hline Activity & Time Driver & Time Consumption \\
\hline Receiving order information (basic activity) & & 2 minutes \\
\hline Picking an item from static shelve & Number of items & 5 minutes/item \\
\hline
\end{tabular}




\begin{tabular}{lll}
\hline Packing a carton & Number of cartons & 1 minute/carton \\
\hline Picking a case by conveyor & Number of cases & 2 minutes/case \\
\hline Picking a pallet by forklift & Number of pallets & 3 minutes/pallet \\
\hline Wrapping a pallet & Number of pallets & 1 minute/pallet \\
\hline
\end{tabular}

TDABC system groups the multiple sub-activities of warehousing process into the following time equation to estimate process time per unit:

Warehousing Process Time per unit $=2$ minutes

( +5 minutes +1 minutes $\times 1 / 4$ if pick and pack items for

individual customers)

( +2 minutes if pick cases for retailers)

wholesalers)

$(+3$ minutes +1 minutes if pick and wrap pallets for

$$
=2+5.25 X_{1}+2 X_{2}+4 X_{3}
$$

where $\mathrm{X}_{1}=$ individual customer $(1) /$ retailer or wholesaler $(0)$

$\mathrm{X}_{2}=$ retailer $(1) /$ individual or wholesaler $(0)$

$\mathrm{X}_{3}=$ wholesaler $(1) /$ individual or retailer $(0)$

During the month, the marketing department picks 2,000 items (500 orders $\times 4$ items) for orders from individual customers, 1,500 cases (300 orders $\times 5$ cases) for orders from retailers, and 600 pallets (200 orders $\times 3$ pallets) for orders from wholesalers. The cost allocation for warehousing process in a TDABC system is shown in Table 10.

Table 10: Cost Allocation for Warehousing Process

\begin{tabular}{lllll}
\hline Cost Object & $\begin{array}{l}\text { Number of } \\
\text { Units }\end{array}$ & $\begin{array}{l}\text { Process } \\
\text { Time* }\end{array}$ & $\begin{array}{l}\text { Capacity Cost } \\
\text { Rate }\end{array}$ & $\begin{array}{l}\text { Cost } \\
\text { Allocated }\end{array}$ \\
\hline Individual & 2,000 items & 14,500 minutes & $\$ 1.67 / \mathrm{min}$ & $\$ 24,166.67$ \\
\hline Retailer & 1,500 cases & 6,000 minutes & $\$ 1.67 / \mathrm{min}$ & $\$ 10,000.00$ \\
\hline Wholesaler & 600 pallets & 3,600 minutes & $\$ 1.67 / \mathrm{min}$ & $\$ 6,000.00$ \\
\hline Total & & $\mathbf{2 4 , 1 0 0}$ minutes & & $\$ \mathbf{4 0 , 1 6 6 . 6 7}$ \\
\hline
\end{tabular}

* Process Time for Individual Customer $=(2+5.25) \times$ Items

Process Time for Retailer $=(2+2) \times$ Cases

Process Time for Wholesaler $=(2+4) \times$ Pallets

** Cost Allocated $=$ Process Time $\times$ Capacity Cost Rate

\section{Shipping Process}

The times required in the shipping activity consist of loading and delivery time. The loading time depends on the type of packages (cartons, cases, or pallets) and the quantity of packages. The delivery time depends on the transport modes (road, rail, ship, air), delivery routes, and number of drop-off points. This study assumes that the delivery expense is assigned to and controlled by Transportation department. The marketing department manages only the loading process. At the shipping dock, the marketing department counts and verify each unit with the order information prior to loading, which takes 5 minutes per unit. It takes an average of 2 minutes to load each carton, 5 minutes to load each case, and 10 minutes to load each pallet. The data about shipping process are summarized in Table 11. 
Table 11: Shipping Process

\begin{tabular}{lll}
\hline Activity & Time Driver & Time Consumption \\
\hline Verifying order information (basic activity) & & 5 minutes \\
\hline Loading a carton & Number of cartons & 2 minute/carton \\
\hline Loading a case & Number of cases & 5 minutes/case \\
\hline Loading a pallet & Number of pallets & 10 minutes/pallet \\
\hline
\end{tabular}

TDABC system groups the multiple sub-activities of shipping process into the following time equation to estimate process time per unit:

Shipping Process Time per unit $=5$ minutes

$(+2$ minutes if load a carton)

$(+5$ minutes if load a case)

$(+10$ minutes if load a pallet $)$

$=5+2 X_{1}+5 X_{2}+10 X_{3}$

where $\mathrm{X}_{1}=$ carton (1) / case or pallet (0)

$\mathrm{X}_{2}=$ case $(1) /$ carton or pallet $(0)$

$\mathrm{X}_{3}=$ pallet $(1) /$ carton or case $(0)$

During the month, the marketing department loads 500 cartons (500 orders $\times 1$ carton per order) for orders from individual customers, 1,500 cases (300 orders $\times 5$ cases per order) for orders from retailers, and 600 pallets (200 orders $\times 3$ pallets per order) for orders from wholesalers. The cost allocation for shipping process in a TDABC system is shown in Table 12.

Table 12: Cost Allocation for Shipping Process

\begin{tabular}{|c|c|c|c|c|}
\hline Cost Object & $\begin{array}{l}\text { Number of } \\
\text { Units }\end{array}$ & $\begin{array}{l}\text { Process } \\
\text { Time }^{*}\end{array}$ & $\begin{array}{l}\text { Capacity Cost } \\
\text { Rate }\end{array}$ & $\begin{array}{l}\text { Cost } \\
\text { Allocated }{ }^{* *}\end{array}$ \\
\hline Individual & 500 cartons & 3,500 minutes & $\$ 1.67 / \mathrm{min}$ & $\$ 5,833.33$ \\
\hline Retailer & 1,500 cases & 15,000 minutes & $\$ 1.67 / \mathrm{min}$ & $\$ 25,000.00$ \\
\hline Wholesaler & 600 pallets & 9,000 minutes & $\$ 1.67 / \mathrm{min}$ & $\$ 15,000.00$ \\
\hline Total & & 27,500 minutes & & $\$ 45,833.33$ \\
\hline \multicolumn{5}{|c|}{$\begin{array}{l}{ }^{*} \text { Process Time for Individual Customer }=(5+2) \times \text { Cartons } \\
\text { Process Time for Retailer }=(5+5) \times \text { Cases }\end{array}$} \\
\hline
\end{tabular}

The process time and costs allocation of 4 primary activities in TDABC are summarized in Table 13.

Table 13: Cost Allocation for All Activities to Cost Objects in TDABC

\begin{tabular}{lllll}
\hline $\begin{array}{l}\text { Primary } \\
\text { Activity }\end{array}$ & Process & \multicolumn{3}{c}{ Cost Object } \\
${ } }$ & 12,850 minutes & $\$ 13,833.33$ & $\$ 5,500.00$ & $\$ 2,083.33$ \\
\hline Selling & 18,200 minutes & $\$ 11,666.67$ & $\$ 12,000.00$ & $\$ 6,666.67$ \\
\hline Warehousing & 24,100 minutes & $\$ 24,166.67$ & $\$ 10,000.00$ & $\$ 6,000.00$ \\
\hline Shipping & 27,500 minutes & $\$ 5,833.33$ & $\$ 25,000.00$ & $\$ 15,000.00$ \\
\hline Total & $\mathbf{8 2 , 6 5 0}$ minutes & $\mathbf{\$ 5 5 , 5 0 0 . 0 0}$ & $\mathbf{\$ 5 2 , 5 0 0 . 0 0}$ & $\mathbf{\$ 2 9 , 7 5 0 . 0 0}$ \\
\hline
\end{tabular}

To determine the marketing department's unused capacity, the supply and demand for its capacity should be compared. The capacity supplied is the marketing department's practical capacity of 90,000 minutes as determined earlier. The demand for 
capacity is the sum of the process time used to perform the department's activities. As indicated at the bottom of Table 13 , the demand for capacity is 82,650 minutes. The difference between the supply and demand for capacity is the marketing department's unused capacity, or 7,350 minutes. The cost of unused capacity is $\$ 12,250$ (i.e., 7,350 minutes $\times \$ 1.67$ per minute). $8.17 \%$ of the capacity in the resources supplied by the marketing department is unused. This information about unused capacity can help the manager make decisions how to reduce the costs of unused resources and to increase efficiency.

Using TDABC, process improvement can be achieved by reducing the capacity required to perform activities and/or reducing the capacity cost rate. Table 13 indicates that the biggest potential for cost savings involves the shipping process which uses 27,500 minutes. Especially, a review of Table 12 shows that the highest process time is taken to serve retailer customers such as 15,000 minutes in loading 1,500 cases. For retailers, a reduction of process time by one minute per case from 5 minutes to 4 minutes would result in reducing the process time by 1,500 minutes and saving costs by $\$ 2,500$ (i.e., 1,500 minutes $\times \$ 1.66$ per minute). The process improvement by decreasing the capacity cost rate for the marketing department can accomplished through saving the general ledger costs of the marketing department in Panel of Table 4. A detailed analysis of each cost is necessary to determine the supply and demand for its capacity and costs with excess capacity have to be reduced (Kee 2012).

\section{Conclusion}

The time-driven activity-based costing (TDABC) method is an appropriate method for the evaluation of marketing activities in terms of the following aspects:

- TDABC emphasizes how long it takes to complete one unit of a certain activity rather than the percentage of time an employee spends doing that activity.

- The TDABC system can be tested and implemented by marketing managers for each separate work process or each sub-activity.

- The TDABC takes into account many aspects that affect employees' efficiency and performance by using a practical capacity which allows rest periods, personal time for breaks, arrival and departure, and communication and reading unrelated to actual work performance.

The TDABC is well suited for marketing setting, involving many activities with complex time drivers. The TDABC seems to be one of the best tools for understanding cost behavior and for refining a cost system for marketing activities. This is also a great method for mapping the companies' activities and processes. Although the documenting the activity flows and data collection to gather the process time can be time-consuming for researcher, and uncomfortable for the staff of being observed, it enables to increase process improvement by shortening the time required to perform certain activities. While integrating the TDABC method with the analysis of marketing performance indicators, the more valuable data is possible to produce for managerial decisions. 
Reliable cost data has become a basic input to various decision makings in companies. The costing method to be used depends on the nature of the problem at hand and the professional judgment of the managerial accountant. Conducting detailed costing technique to ensure high degree of accuracy demands more time, energy and money for compiling and supplying relevant cost information. In selecting costing approaches among traditional costing, conventional $A B C$, and TDABC, therefore, consideration of cost-benefit trade off becomes necessary. A general conclusion which could be made from the existing literature is that costing technique is crucial in various decisions and plays an important role in managerial decision making.

\section{References}

Beik, L. and S. Buzby (1973), "Profitability Analysis by Market Segments," Journal of Marketing, pp. 48-53.

Brimson, J. (1991), Activity Accounting: an activity-based costing approach, John Wiley \& Sons: New York, NY.

Everaert, P. and W. Bruggeman (2007), "Time-driven Activity-based Costing: Exploring the Underlying Model," Cost Management, pp. 16-20.

Hoozee, S. M., L. Vermeire, and W. Bruggeman (2012), "The impact of refinement on the accuracy of time-driven ABC," Abacus, pp. 439-472.

Kaplan, R. and S. Anderson (2004), "Time-Driven Activity-Based Costing," Harvard Business Review, pp. 131-138.

Kaplan, R. and S. Anderson (2007), "Time-Driven Activity-Based Costing: A Simpler and More Powerful Path to Higher Profits," Harvard Business School Press: Boston, MA.

Kaplan, R.S. and R. Cooper (1998), "Cost \& Effect. Using Integrated Cost Systems to Drive Profitability and Performance," Harvard Business School Press: Boston, MA.

Kee, R. C. (2012), "Measuring \& Managing the Cost of Governmental Services: A Case for TimeDriven Activity-Based Costing," Journal of Government Financial Management, pp. 38-41.

Lilien, G., P. Kotler, and K. Moorthy (1992), Marketing Models, Prentice Hall: Englewood Cliffs, NJ.

Minter, S. (2014), "US, Mexico Are 'Rising Stars' in Manufacturing Cost Competitiveness," Industry Week.

Mittal, V., M. Sarkees, and F. Murshed (2008), "The Right Way to Manage Unprofitable Customers," Harvard Business Review

Narong, D. K. (2009), "Activity-based costing and management solutions to traditional shortcomings of cost accounting," Cost Engineering, pp. 11-18.

Sidhu, B. and J. H. Roberts (2008), "The marketing accounting interface - lessons and limitations," Journal of Marketing Management, pp. 669-686.

Spedding, T. A. and G. Q. Sun (1999), "Application of discrete event simulation to the activity based costing of manufacturing systems," International Journal of Production Economics, pp. 289301.

Wegmann, G. and S. Nozile (2009), "The activity-based costing method developments: state-of-the art and case study", The IUP Journal of Accounting Research and Audit Practices, pp. 7-22.

Weber, J. (2002), "Managing the Marketing Budget in a Cost-Constrained Environment," Industrial Marketing Management, pp. 705-717. 